\title{
Study the variations of sinkhole depth with respect to working height in underground coal mines
}

\author{
Poonam Sahu, Manoj Pradhan and Ravi K Jade \\ National Institute of Technology \\ Raipur, India \\ riteshlokhande@gmail.com
}

\author{
Ritesh D Lokhande \\ Visvesvaraya National Institute of Technology \\ Nagpur, India \\ riteshlokhande@gmail.com
}

\begin{abstract}
Minerals extraction from underground mine may lead to the disturbance in equilibrium of the overlying strata and these disturbances reflect in the form of subsidence on the surface. Subsidence is of two types, trough and sinkhole subsidence. Sinkhole subsidence is an abrupt local depression at the surface due to underground excavation which can be hazardous to life and property due to its tendency to occur without admonition. Sinkholes occur due to the failure of a mine roof which migrates through the overlying strata until the failure zone intercepts the unconsolidated overburden. It is generally assumed that the depth of sinkhole subsidence occurs is same as the working height but in field investigations it was observed that this implication is not withstanding on the actual working and needs detailed analysis work. Considering this study, authors presented detailed analysis of field investigations which occurred in some of the coal mines of South Eastern Coalfields Limited (SECL) in this paper.
\end{abstract}

Keywords-Underground coal mine; sinkhole subsidence; depillaring; development

\section{INTRODUCTION}

The earth's surface can subside because of underground mining when rock is removed at depth. Although subsidence can occur due to hard rock mining. When coal is extracted underground, gravity and the weight of the overlying rock may cause the layers of rock to shift and sink downward into the void left by the removal of the coal. Ultimately, this process can affect the surface, causing the ground to sag and crack and holes to form[1].

There is a growing trend of human occupation near mining sites due to foreseen benefits of employment and livelihood. Sinkhole formation in such locations can be dangerous for social-life and often lead to severe damage to surface features by causing collapse of buildings [2].

It occurs in two forms, trough and sinkhole subsidence. Trough subsidence usually occurs in greater depth where as sinkhole, at shallow depth of cover. Sinkhole is a localized phenomena occurring due to sudden collapse of cover into the underground voids [3]. (Fig.1) [4],shows the sinkhole subsidence. Sinkhole is the most dominant phenomenon which frequently occurred in the mines of South Eastern Coalfield Limited (SECL), Coal India Limited. In this paper detailed

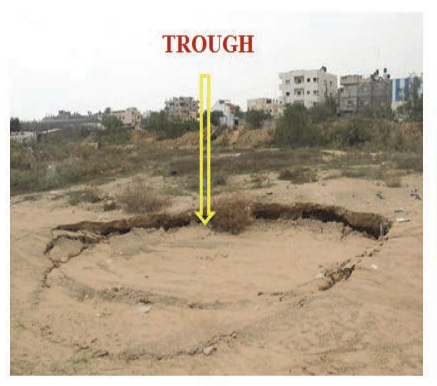

(a)

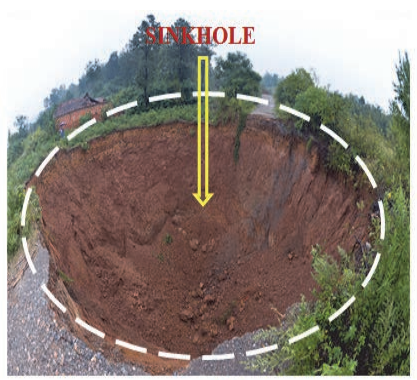

(b)
Fig. 1. Types of subsidence (a) Through subsidence (b) Sinkhole subsidence

Sinkhole is extremely hazardous as it can happen suddenly and without warning as shown in (Fig. 2) [5].

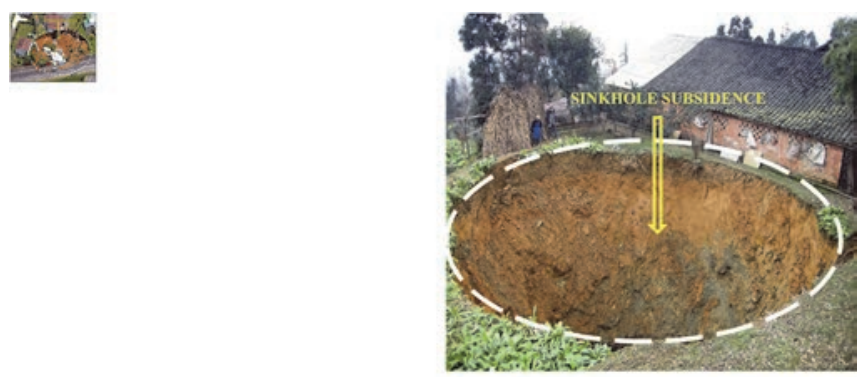

Fig. 2. Impact of sinkhole to the social-life and property

field investigations of sinkhole subsidence cases at SECL and its analysis with respect to presence of geological fault in different working status.

\section{MODE OF ORIGIN}

Underground excavations created for coal mining purpose may create cavities in the subsurface due to deformations and displacements of the overlying strata, the extent of which depends on the magnitude of the in-situ stresses, mining induced stresses, void size, immediate roof characteristics and presence of geological discontinuities. With time, these cavities may enlarge as remnant pillars left to support immediate roof deteriorate and the superjacent strata moves into the voids, resulting in instability of underground workings [6]. Gradually, these movements work up to the surface to form a depression on the ground surface, which is commonly referred to as subsidence as shown in (Fig. 3) [7]. Surface subsidence generally entails 
both vertical and lateral ground movements. It manifests in three major ways, namely, cracks, troughs or sag and sinkhole subsidence [8].

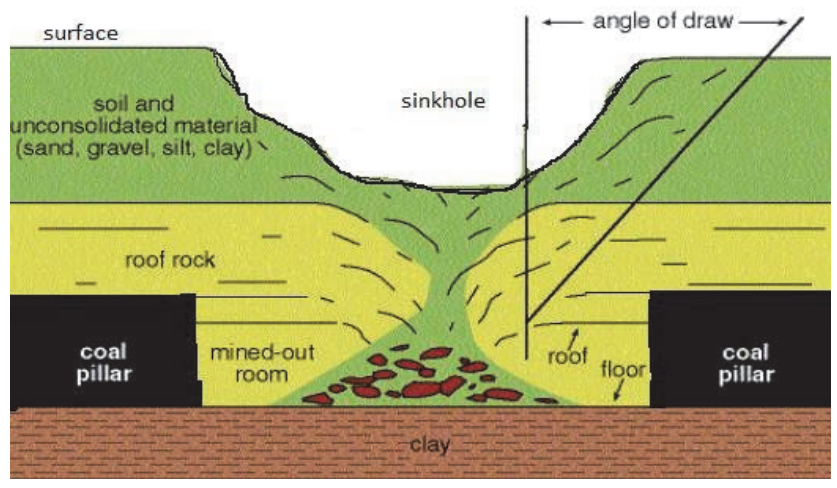

Fig. 3. Formation of Sinkhole Subsidence

\section{FIELD INVESTIGATION}

Subsidence investigations were carried out at Sohagpur and Korba coalfields located in different parts of India, namely, Madhya Pradesh and Chhattisgarh state as shown in (Fig. 4) [9].

The detailed study was done at different mines of two areas of India, namely, Jamuna Kotma and Korba area where sinkhole subsidence problem is very common. Total 24 sinkholes were studied due to presence of fault in different working conditions.

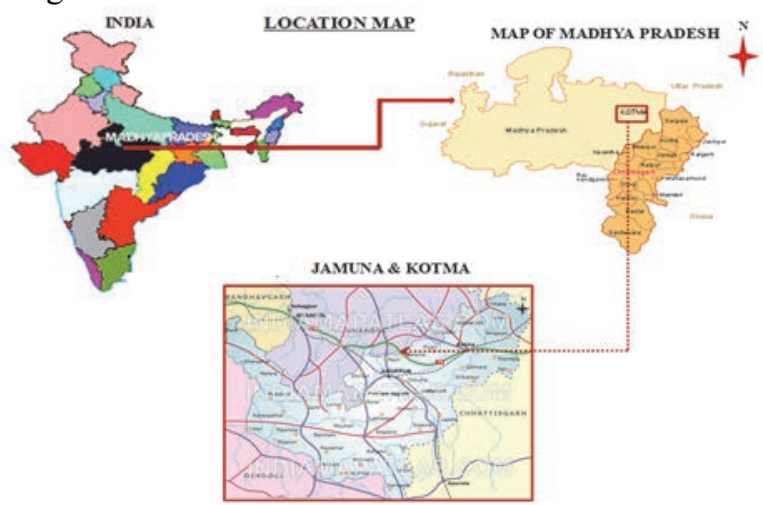

Fig. 4. Location of study area of SECL

Field investigation were targeted in different types of geological disturbed area which prone for the sinkhole subsidence. Accordingly, study has been conducted in two areas of SECL. All the sinkhole occurred over bord and pillar development and depillaring workings. The cover depth varied from 15 to $64 \mathrm{~m}$. The dip of the seam varied from 1 in 6 to 1 in 40 .

\section{GEOLOGY OF THE AREAS}

The mines of Jamuna Kotma Area form a sub-basin in the south-central portion of the Sohagpur coalfield. In this coalfield Gondwana sediments are essentially comprised of Barakars and Supra-Barakar, which are separated from Deccan Traps of the Maikal Range by a narrow range of Lameta beds in the western half and eastern, half of the coalfield. The southern boundary is demarcated by Talchirs which rest unconformably over the Achaeans [10].The geological map has been properly demonstrated in (Fig. 5) [11], and the Korba coalfield is trending in E-W direction conforming the regional strike of the basement rocks Precambrian. The coal bearing strata covers an area of about 500 sq.kms. Out of which 150 sq. kms. lies to the east of Hasdeo river and the larger part of it lies to west. A narrow strip of Barakar sediments continues up to Ahiran valley, in the N-W. To the east, coal measures pass under Kamthi formation under watershed between Hasdeo and Mand river. A thin strip of Barakar strata also connects the coal measure of Mand river valley [12]. The geological map of the Korba coalfield is shown in(Fig. 6) [12]

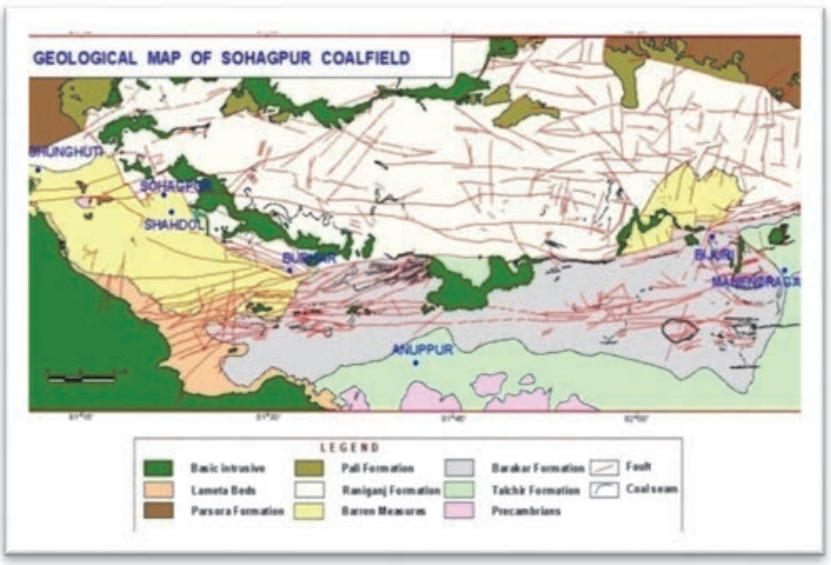

Fig. 5. Geological map of the Sohagpur coalfield

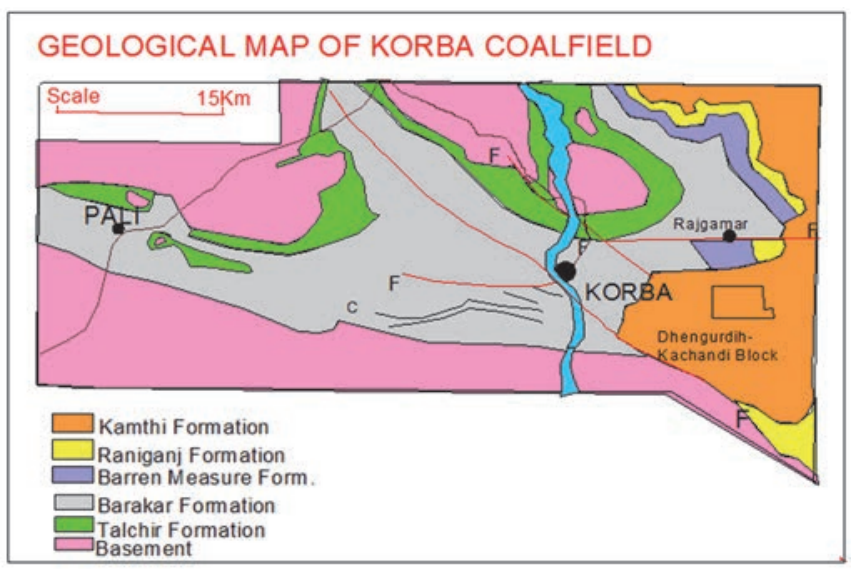

Fig. 6. Geological map of the Korba coalfield

\section{OBSERVATION AND DISSCUSSION}

It can be seen from the investigations the total nine sinkholes where occurred over depillared workings with the maximum sinkhole depth was $14 \mathrm{~m}$ whereas fifteen sinkholes were occurred over development workings with the maximum sinkhole depth were $60 \mathrm{~m}$. In (Fig. $7)$, the variation of sinkhole depth is shown.

- In development workings a total nine numbers of sinkholes occurred with the maximum throw of fault is $15 \mathrm{~m}$ and fault distance near to sinkhole is $30 \mathrm{~m}$. 
- In depillaring workings a total 15 numbers of sinkholes occurred with the maximum throw of fault is $34 \mathrm{~m}$ and two sinkholes $\left(\mathrm{M}_{1}\right.$ and $\left.\mathrm{S}_{1}\right)$ reported near to fault plane.

- The shapes of all the sinkholes are circular whose diameters varied from $8 \mathrm{~m}$ to $35 \mathrm{~m}$ in depillared workings and $1.50 \mathrm{~m}$ to $6 \mathrm{~m}$ in development workings.

- The sinkholes $\mathrm{J} 1$ is directly observed in fault plane and due to presence of dislocation of rocks in depillared workings. The depth of the dislocation observed $60 \mathrm{~m}$ vertical interface (Fig. 8), showing a part plan of location of sinkhole no. $\mathrm{J}_{1}$ with site investigation and borehole section.

- In one of the mine of Korba area, fault plane was crossed from the sinkhole location with throw of $24 \mathrm{~m}$. The main reason of sinkhole was due to the presence of fault plane and the shallow cover in development working. The part plan shows the location of the sinkhole number $\mathrm{D}_{1}$ and the photograph shows at the time of occurrence and after filling of sinkhole with their borehole section in (Fig. 9).

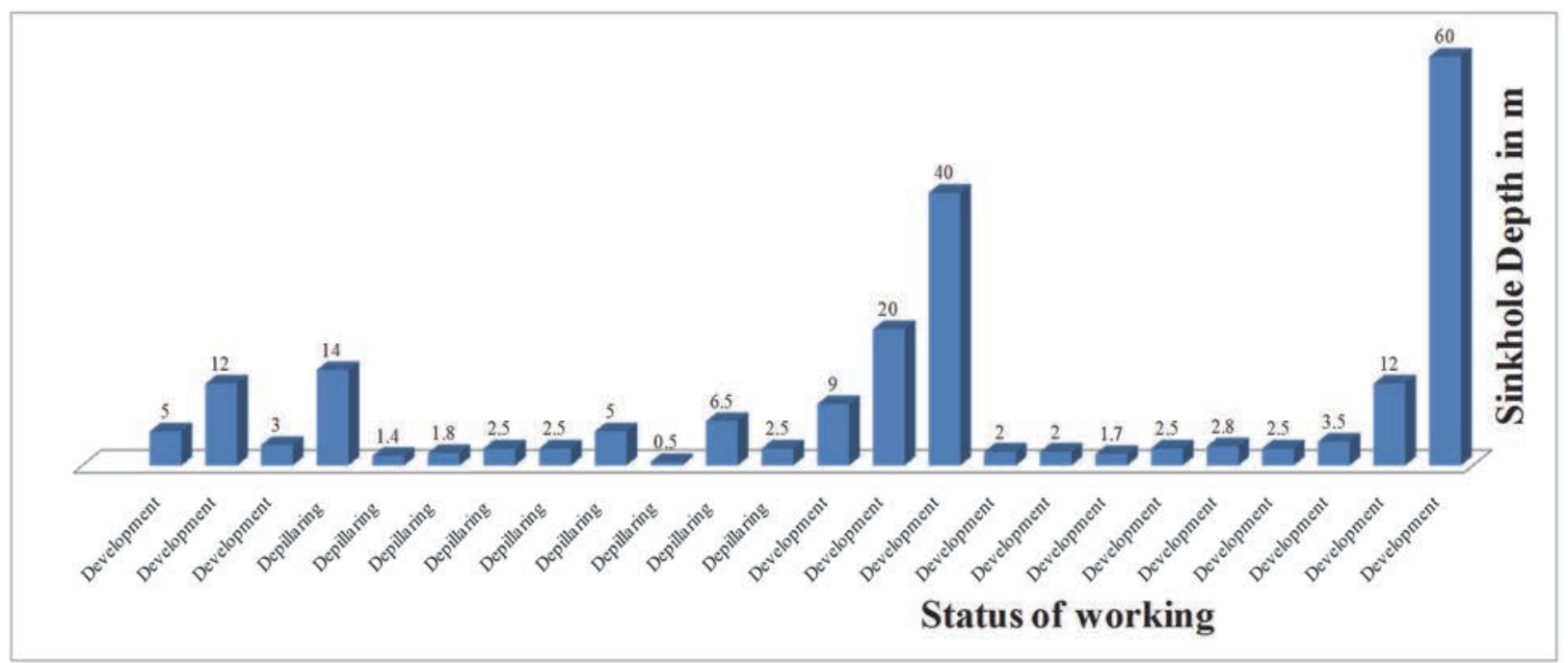

Fig. 7. Sinkhole depths in different working status

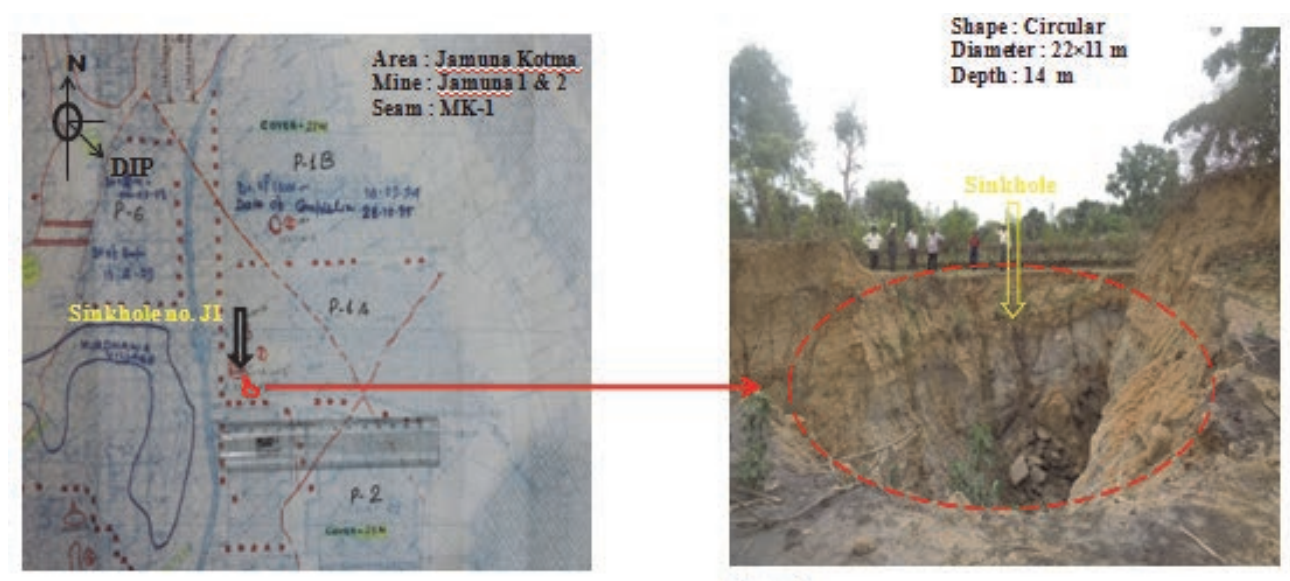

Borehole section near sinkhole no. $\mathrm{J}_{1}$

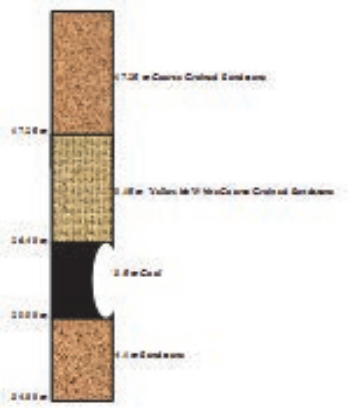

Fig. 8. Part plan showing location of sinkhole number $\mathrm{J}_{1}$ with borehole section 


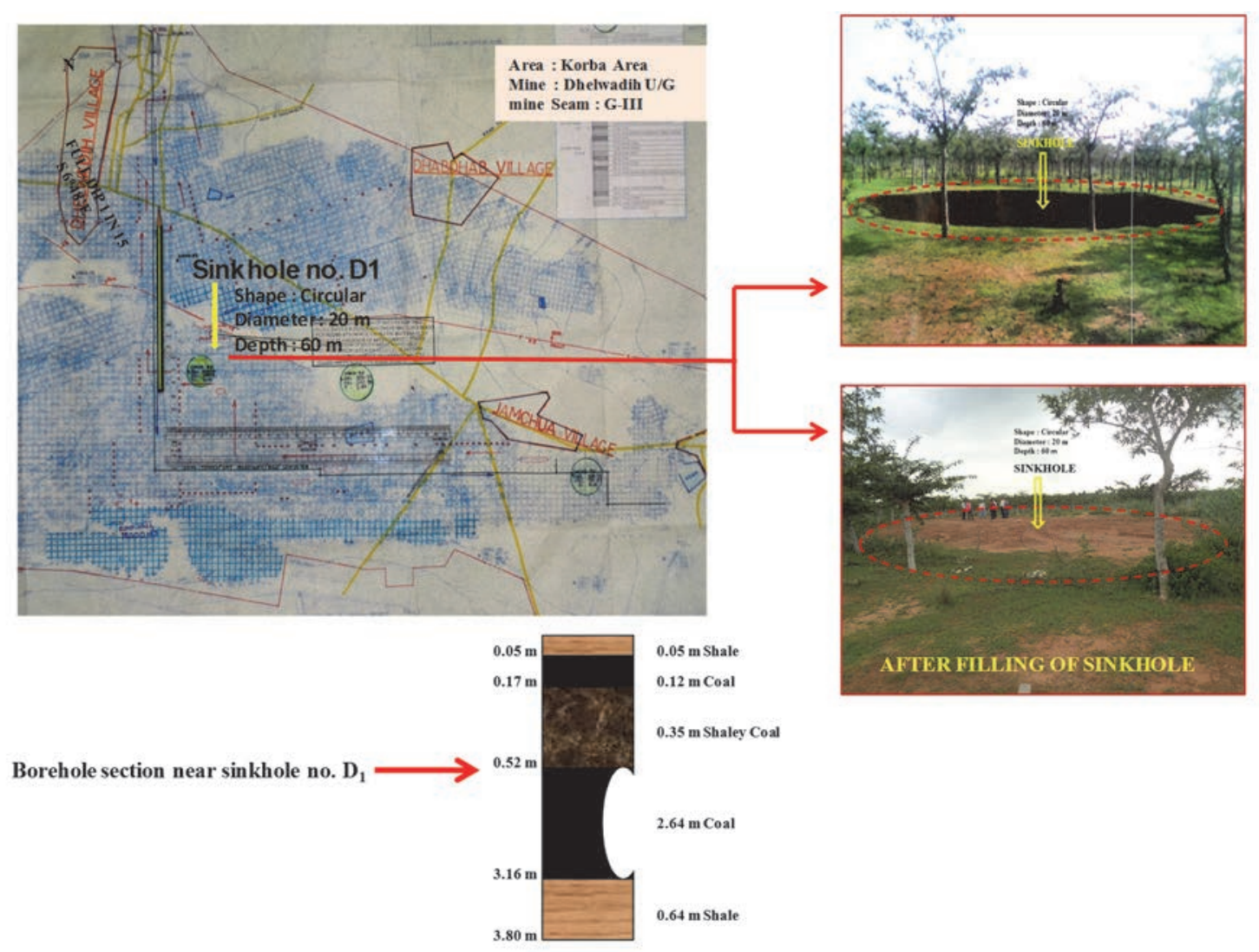

FIG. 9. Part plan showing location of sinkhole number D1 with borehole section

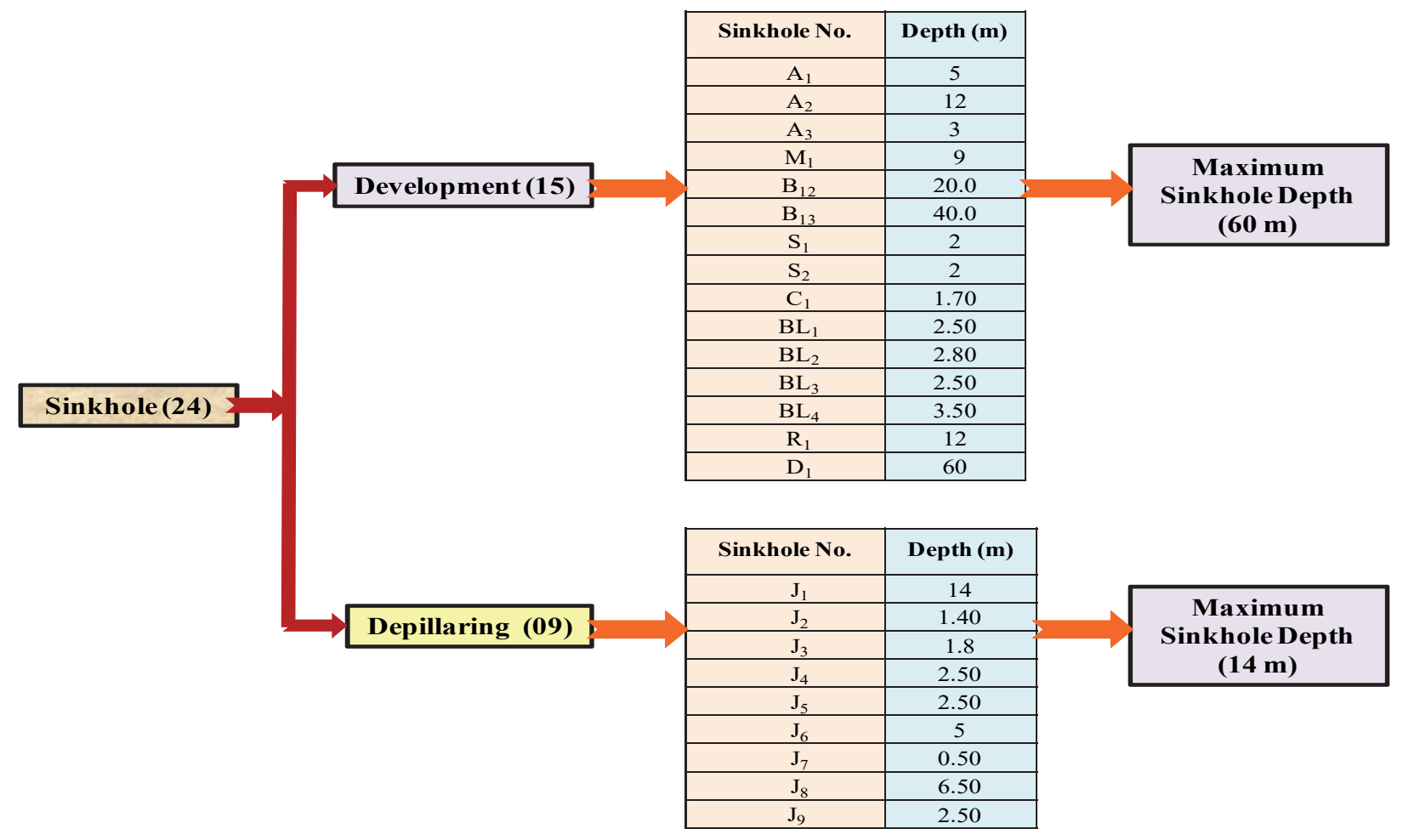

Fig. 10. Details of Sinkhole at different status of working 


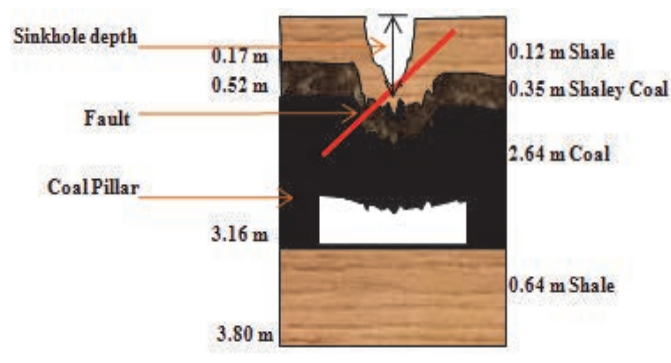

(a)

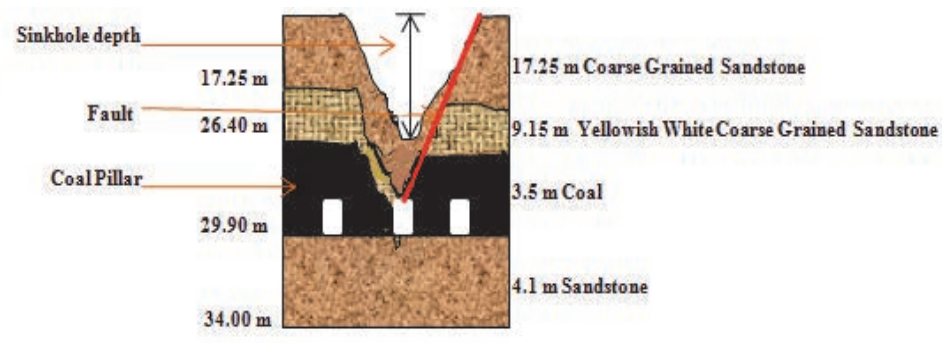

(b)

Fig. 11. (a) Occurrence of Sinkhole no $J_{1}$ is depillaring working (b) Occurrence of Sinkhole no $D_{1}$ in development working

\section{VARIATION OF SINKHOLE DEPTH IN DIFFERENT WORKING STATUS}

There are two stages of underground coal mining, namely, development and depillaring. In development driving galleries and making roadways will not cause much roof deformation unless there are geological discontinuities associated with heavy water seepage. Sinkhole condition arises due to the presence of discontinuities within the working (Fig. 10), shows a details of the total 24 sinkholes with their depth.

In depillaring, the coal extraction percentage is higher and sinkhole risk is also high. The (Fig. 11a \& 11b), shows sinkhole $\mathrm{J} 1$ and D1 in depillaring and development cases respectivelyLokhande et al. [13-15] has used this parameter in their research work for the development of the sinkhole subsidence prediction model.

\section{CONCLUSIONS}

In this study, analysis of field investigations work revealed that geological structures like fault, fissure and slip are playing important role for triggering the sinkhole subsidence. In addition to that weak \& saturated lithology and overburden are also playing the important role for occurring sinkhole. In Jamuna Kotma and Korba area of SECL are facing sinkhole problem due to shallow depth and presence of geological structures. The variation in the depth of sinkhole with respect to the working height is mainly because of fault. The movement of eroded materials from saturated and weathered super-incumbent with water along a fault plane into the underground at the opening in the subsurface or cavity which leads the variations in the depth of sinkhole with respect to working height. All the 24 sinkholes which have been investigated in these two areas were occurred due to the presence at fault plane.

\section{ACKNOWLEDGEMENT}

The authors express their sincere gratitude to Head of Department of Mining Engineering and Directors of VNIT, Nagpur and NIT, Raipur, CMD SECL, for providing necessary support and permission to conduct the study. Also authors are very much thankful to Prof. VMSR Murthy, IIT (ISM), Dhanbad and Dr. K B Singh, Scientist, CIMFR for their valuable contribution in the field of sinkhole subsidence which motivates us to do this study. The views expressed in this paper are those of the authors and not necessarily of the organizations they represent.

\section{REFERENCES}

[1] www.subsidence.neoscenes.net/Accessed on $25^{\text {th }}$ December, 2015.

[2] Lokhande D. Ritesh, Murthy Vemavarapu M.S.R., and Vellanky Venkateswarlu, "Assessment of pot-hole subsidence risk for Indian coal mines" International Journal of Mining Science and Technology, vol. 25, pp. 185-192, 2015.

[3] Lokhande R.D., Murthy V.M.S.R., and Singh K.B., "Pot-hole Sabsidence in Underground Coal Mining: Some Idian Experience”, An International Journal of Geotechnical and Geological Engineering, Vol 31, pp 793-799, 2013.

[4] www.chinadaily.com.cn/Accessed on $8^{\text {th }}$ February, 2015.

[5] www.laneassociates.co.nz/Accessed on $10^{\text {th }}$ October, 2015.

[6] Karfakis Mario G., Mechanism of chimney subsidence over abandoned coal mines, Proceedings of the 6th International conference on Ground Control in Mining, 9-11 June, Morgantown, WV, 1987.p.195-203.

[7] www.minesub.nsw.gov.au/Accessed on $10^{\text {th }}$ October, 2015.

[8] Sahu Poonam, and Lokhande Ritesh D, "An Investigation of Sinkhole Subsidence and its Preventive Measures in Underground Coal Mining" Procedia Earth and Planrtary Science, vol. 11, pp 63-75, 2015.

[9] www.avanthapower.com/Accessed on $8^{\text {th }}$ February, 2015.

[10] Report on Hydrogeological Investigation Carried out at Meera Incline, Jamuna and Kotma area, Dist. Shahdol (M.P.), Nceon Underground CMPDI, May 2002.

[11] Mukhopadhyay A. , S.K., Adhikari, S. and Mondal, A. (2011). “ Geology of Sohagpur coalfield, Bilaspur and Koriya districts, Chhattisgarh and Anuppur and Shahdol districts, Madhya Pradesh". Bulletin Series-A No. 55.

[12] Raja Rao C.S. (1983). "Coal fields of India Vol. III: Coal resources of Madhya Pradesh, Jammu and Kashmir. Bulletins of Geological Survey of India, Series A, Vol.45, pp.75-80.

[13] Lokhande R D, An investigation into the causes of pot-hole subsidence and its prediction in underground coal mining, Thesis of Doctorate of Philosophy in Mining Engineering, ISM Dhanbad, India, 2013.

[14] Lokhande R D, Murthy V M S R and Singh K B, "Predictive models for pot-hole depth in underground coal mining- Some Indian Experiences" Arabian Journal of Geosciences, Vol. 07, No.11, 2014, pp. 4697-4705.

[15] Lokhande R D, Murthy V M S R and Singh K B, "Predictive models for pot-hole depth in underground coal mining- Some Indian Experiences" Arabian Journal of Geosciences, Vol. 07, No.11, 2014, pp. 4697-4705. 